\title{
The Schools Band Contest of America (1923)
}

\author{
EMIL A. HOLZ
}

T

he Schools Band Contest of America was held in Chicago on June 4, 5, and 6, 1923. ${ }^{1}$ Although only 30 bands competed, the contest achieved importance in the history of music education because it led directly to that spectacular series of competition-festivals that dominated the world of secondary school music from 1926 to 1941. It provided the occasion and the reason for the merging of musical, educational, and commercial efforts in a common cause- the simultaneous democratization and artistic improvement of instrumental music in the schools. The forces set in motion by this event thrust the school band, long among the lowliest of school music groups, into a position of prominence.

\section{Historical Background}

For 50 years after Lowell Mason introduced singing classes into the grammar schools of Boston in 1838, instrumental music occupied a very minor place in school life. Bands and orchestras appeared sporadically during the last half of the nineteenth century, but few were able to perpetuate themselves or find a place in the secondary school curriculum. Even vocal music, with a half-century head start, had remained an extracurricular activity in secondary schools. The rigidly academic program

${ }^{1}$ This article is based upon information contained in the writer's Ph.D. dissertation, "The National School Band Tournament of 1923 and Its Bands" (The University of Michigan, 1960). of the American high school in the years following the Civil War precluded the offering of "practical" or "artistic" subjects.

During the last decade of the nineteenth century, the onrushing urbanization of American social life led to an increase in secondary school enrollments that more than quadrupled the number of students attending public high schools in the 25 years between 1885 and 1910. Coincidentally with this population explosion, demands that schools undertake activities and services formerly within the provinces of home and church spurred the formation of child health centers, child guidance clinics, school nursing programs, hot lunch programs, and vacation playgrounds. During the same period, public playgrounds were established, interscholastic athletics became popular, and programs of military training were instituted in a number of schools. By the end of the first decade of the twentieth century, the platoon school and the junior high school appeared. Courses proliferated rapidly as the schools sought to serve their new clientele and meet the needs of society. Vocational and citizenship courses sprang up in great variety. These swift and far-reaching changes in social and educational life enabled the firehouse band and the Sunday school orchestra to move into the schoolhouse.

The urge to support their fellows on the athletic field often led students to organize nondescript bands. Occasionally, progressive administrators or mu- 
sic supervisors established bands to stimulate school spirit or to provide a musical activity for boys unable or unwilling to sing. Such bands depended upon the availability of students who had access to private instruction although some attempts at group teaching were made. Directors of school bands before 1920 were often part-time employees whose main interests were in professional music. Frequently a teacher of an academic or vocational subject, interested in boys and in band music, assumed the responsibility of a student band.

Since early school bands were usually organized in response to social demands, the quality of instrumentation and repertoire-to say nothing of performance - was often abysmally low. Marches, waltzes, two-steps, "smears," and ragtime, played badly but enthusiastically by a dozen boys, represented school band music. A student band might essay an operatic overture or potpourri, but the inadequacies of personnel, instrumentation, and instruction usually limited the repertoire to music of more modest pretensions.

During the second decade of the century, and particularly after the end of World War I, school bands grew in number and the quality of instruction improved. Veterans, trained in military bands, found positions in the schools and organized bands. A few mid-western state contests for school musicians began to include events for bands. Although vocal music had begun to find a place in the secondary school curriculum, bands and orchestras remained extracurricular. No effective organization of band directors existed, and bandmen, because they were part-time employees or teachers of non-music subjects, did not participate in the work of the Music Supervisors Nation- al Conference. The supervisors, on their part, tended to ignore the school band.

Shortly after its organization in 1907, the Conference had begun the study of the possibility of securing scholastic credit for secondary school music. In 1912 a special committee proposed that accreditation be sought for music activities in the following order: Chorus, music appreciation, girls chorus, band, and boys chorus or glee club. The low position assigned to the band reflected the reluctance of the committee to encourage the raucous, untutored band at the expense of other musical activities. For the next decade, although the Conference gave more and more of its attention to instrumental music, the band was usually discussed parenthetically, if at all, at annual meetings.

In spite of statements on behalf of school bands by Glenn $\mathrm{H}$. Woods in 1914, F. M. Hunter in 1916, and W. Otto Miessner in 1919, the Conference did not seriously consider the band and its problems until 1923 at the Cleveland meeting. (Some attention had been given to bands at the 1921 meeting at St. Joseph, Missouri, but the discussions at that time were limited to participants at sectional meetings.) At Cleveland, the entire membership heard three band performances and listened to the report of the yearold Committee on Instrumental Affairs, headed by Jay W. Fay. Edgar B. Gordon addressed the Committee and many of the supervisors at a sectional meeting. According to Gordon, "The high school band is no longer an incidental school enterprise prompted largely by the volunteer services of a high school teacher who happens to have had some band experience, but rather an undertaking which is assigned to a definite place in the school schedule with a 
daily class period under a trained instructor and with credit allowed for satisfactory work done." 2

The Conference had finally accepted the band as one of the elements of the school music program. The Committee on Instrumental Affairs, however, continued to be concerned with the problems that had led to its formation -class instruction, a census of instrumental teachers, minimum requirements for instrumental supervisors, and a list of suitable materials for school orchestras. One year later the Committee was to be engaged in the unexpected and unwelcome task of organizing band contests.

While school bands were growing in number, amateur and professional bands were disappearing rapidly. From the 1840's, after the introduction in America of Adolphe Saxe's perfected brass instruments, the band had provided the most widely disseminated form of musical entertainment in the nation. By 1890 perhaps as many as 10,000 bands were in existence. ${ }^{3}$ The successful tours of Patrick Sarsfield Gilmore and John Philip Sousa had stimulated the enthusiasm for bands so greatly that Austin A. Harding could report in 1915 that at one time the state of Illinois had had more bands than towns. ${ }^{4}$ Bands could be found everywhere - in schools, universities, factories, department stores, churches, amusement parks, prisons, seminaries, and schools for the feeble-minded. Most were small (perhaps 10 to 16 men) but

2"The Band as a School and Community Asset," MSNC Journal of Proceedings (Ann Arbor, Michigan: The Conference, 1923), p. 172.

${ }^{8}$ Leon Mead, "The Military Bands of the United States," Harper's Weekly, September 28, 1889 , p. 785 .

"Austin A. Harding, "The Band as a Community Asset," MTNA Volume of Proceedings (Hartford, Conn., 1915), p. 188. many numbered 30 or more and a few boasted 100 musicians. These thousands of bands provided music for parades, civic ceremonials, concerts, and dances. As the popularity of Sousa and the other great bandleaders increased, a host of imitators appeared. The intense competition that developed led to price-cutting and charlatanism. As quality deteriorated the attraction of the town or park band waned. By 1920 many had succumbed under the simultaneous attacks of jazz, the automobile, the moving picture, and the phonograph. The great concert bands ceased touring and village bandstands stood deserted.

With the decline of professional and amateur bands the band instrument industry was in danger. Quantity production methods, necessary for economic health, required a large and growing market. From at least as early as the 1870's manufacturers had established bands, advised novice leaders, helped barber-baritone players and tanner-trombonists find work in communities with town bands, and offered instruments as prizes in band contests. The propagandizing efforts of individual companies within the industry had stimulated the growth of school band contests, led to the organization of school bands, and introduced instruction manuals and class instruction books. Promotional ventures encompassing the entire band instrument industry had not yet been undertaken when the idea for the Schools Band Contest of America was broached, although the manufacturers and dealers in some other segments of the music trade had cooperated in encouraging the sales of their products.

By the spring of 1923 all the ingredients that were to make the national band contest movement possible had 
been assembled. A large number of school bands had come into existence, a committee of dedicated music supervisors had become seriously interested in the school band, and the band instrument industry had become desperately in need of increased sales. The catalyst that set these ingredients to work was a national contest for school bands.

\section{The National Band Tournament of 1923}

The first national contest for school bands was called, on letterheads and in official correspondence, "The Schools Band Contest of America." Contemporary newspaper accounts referred to the event as a "tournament." For the sake of brevity and to distinguish this event from the later contests held under the auspices of national associations, the term "tournament" will be used throughout this article to refer to the contest of 1923 .

The tournament resulted from a search by members of the Chicago Piano Club, a dealers' association, for entertainment for the annual convention of the Music Industries Chamber of Commerce, an association of manufacturers, publishers, and dealers that was to meet in Chicago from June 3 to 7 , 1923. Sometime during March 1923, Victor J. Grabel, then director of the band at the Cicero plant of the Western Electric Company, told members of the entertainment committee that band contests had been very popular in Wisconsin several years earlier when he had been teaching in that state. The officers of the Piano Club were enthusiastic. They suggested to Carl $D$. Greenleaf (president of C. G. Conn, Ltd., and also at that time president of the Band Instrument Manufacturers' Association) that the band instrument makers would be the logical group to organize and finance such a project. ${ }^{5}$ A fund of $\$ 10,000$ was raised to cover the expenses of the tournament (supposedly through industry. wide solicitation although the contribu. tions of individual manufacturers have not been revealed).

Late in March or early in April, Greenleaf assembled a planning committee consisting of himself, Bohumir Kryl, E. H. Kleffman, and Frank L. Beals. Kryl, director of a popular touring concert band, had been associated with promotional efforts by the Conn Company. Kleffman had assisted H. A. VanderCook in the teaching of music by correspondence and had written articles on violin technique, orchestral violin playing, and interpretation. $\mathrm{He}$ had directed the band at Harrison Technical High School in Chicago since 1919. Beals was a retired army officer who had reorganized the high school cadet corps in Chicago in 1917 and 1918 and had continued to supervise military training after the creation of the Junior ROTC in 1919. Since all public high school bands in Chicago were connected with the ROTC, Beals was, in effect, supervisor of bands. Part of his work was the organization and control of annual competitions for ROTC units and their bands. Victor J. Grabel and William F. Ludwig were also consulted about the operation of the tournament but their advice was ignored. ${ }^{8}$

\footnotetext{
${ }^{5}$ Although as a promotional organization the National Bureau for the Advancement of Music had been active since 1916, its efforts in 1923 were largely limited to the promotion of piano classes and the stimulation of sales of reproducing pianos. It is probable that the piano dealers, who supported the Bureau by paying a "tax" of fifty cents on every piano sold, were unwilling to permit use of their funds for the benefit of a competitive branch of the music industry.

${ }^{6}$ Letter from Victor J. Grabel, December 14, 1959; letter from William F. Ludwig, Sr., January 7, 1960.
} 
Patrick Henry, an advertising agent, was engaged to organize the tournament and to exploit the event in the interests of the band instrument manufacturers and of the music industry as a whole. Henry immediately mailed announcements of the forthcoming contest to directors whose names were available on certain manufacturers' mailing lists. The preliminary announcement, mailed not earlier than April 3, offered $\$ 6,000$ in cash prizes, plus instruments, medals, and ribbons, to the best high school, grammar school, and military school bands with a first prize of $\$ 1,000$ for the best band in each division. Directors were urged to request further information by returning an enclosed postal card. Subsequent mailings stated the rules of competition and announced plans for the accommodation of contestants.

Almost simultaneously with the receipt of the first applications for entry, Henry opened a barrage of newspaper stories about the tournament, announcing that 6,000 students were expected to participate in 200 school bands from all over the nation. About a week before the tournament, he announced that 200 bands had been eliminated, purportedly by preliminary competitions, and that 35 carefully selected bands would appear in Chicago for the final contest. Actually, any eliminations that occurred resulted from the late notice and the reluctance of some directors and school officials to enter a contest so blatantly commercialized. Thirty bands finally appeared at the tournament, 15 of them from Chicago and its immediate area.

During the tournament, Henry capitalized on the presence of girls in a few bands, the popularity of jazz, the extreme youth of some of the participants, and the entrance of a Negro band in the competition to support the main propaganda objectives of the convention-music for everyone and "jazzier jazz bands." A 12-year-old Negro boy from Hannibal, Missouri, was quoted in headlines throughout the nation as saying, "Music am jes' fun." A girl from Harvey, Illinois, was quoted as moaning, "If only we could play jazz." At the final massed band program, a seven-year-old boy, Raymond Baird (called "Little Sousa"), conducted a march, apparently to convince skeptics that music was easy, after all. The publicity was widely disseminated and given front-page prominence or featured positions on inside pages. Several of the competing bands broadcast their efforts from a radio station in the Drake Hotel, headquarters of the convention.

Although the planting of promotional publicity was most carefully and effectively conducted, the tournament itself was poorly organized, at least by the standards of the elaborate contests of the 1930's. Housing was provided in a huge barracks-like room on Navy Pier (now called Municipal Pier) where army cots were set up within enclosures of fragile wooden fences. High school ROTC cadets and officers provided the only supervision. Each boy had been instructed to bring one blanket and no other bedding seems to

\footnotetext{
TThe quotation comes from a headline, "Jazzier Jazz Bands in Musical Offing," that appeared in the Chicago Daily News on June 6, 1923. The lead paragraph began: "How to make jazz bands jazzier seems to be the chief concern nowadays of the inventive minds in the world of instrument manufacturing if one can believe eyes and ears at the Drake Hotel today." Two days earlier, on the opening day of the tournament, the News informed its readers that the Negro school band from Hannibal, Missouri, was "admitted by all the boys [at the tournament] to play the best jazz of any band on the pier."
} 
have been provided. Meals were obtainable at a cafeteria on the pier. The ballrooms, penny arcades, and other carnival attractions located on the pier provided the "entertainment galore" promised by Patrick Henry's final letter to contestants. The few girls who appeared (to the surprise and delight of officials) stayed at downtown hotels or at the YWCA.

The competition was conducted in Grant Park near the Congress Hotel and the Art Institute where a temporary wooden bandstand had been erected between Michigan Avenue and the tracks of the Illinois Central Railroad. At a little distance, a smaller platform, graced by a huge umbrella, was built for the judge and his secretary. Bands were expected to march from the pier to the bandstand, there to compete with noises from avenue traffic and the railroad yards as well as against other bands.

The single judge (despite the announcement of a panel of judges of world-wide reputation) was Lieut. William H. Santelmann, director of the United States Marine Corps Band. He was to rate each band in tone quality, expression, intonation, and precision, 10 points representing perfection in each category. Bands were also to be rated on deportment. The employment of a single judge provoked severe criticism of the tournament from several competing directors who had participated in contests before panels of judges and knew the advantages of group appraisal. Other directors complained that the adjudication standards announced by Santelmann through the Chicago papers disagreed with those stated in Patrick Henry's letters to them.

There was no list of numbers from which competition pieces were to be selected. Consequently, each band played whatever it had been able to prepare in the six or seven weeks between the receipt of the first notice and the date of the tournament. A few bands used music learned for local and state contests not connected with the tournament. There were also no requirements for the size or instrumentation of competing groups. The smallest band in the high school group (from Paw Paw, Michigan) numbered 25with a woodwind section of three clarinets and a saxophone. Bands of 70 or 80 members appeared from Gary, Indiana, and Fostoria, Ohio. Only a few bands boasted oboes, bassoons, or French horns.

Because only 30 bands had entered, the tournament, originally scheduled to begin on the morning of Monday, June 4, did not start until the following day. Eleven high school bands played before Santelmann on Tuesday and 14 high school bands competed on Wednesday. On Thursday morning, Santelmann heard one late-arriving high school band and four grammar school bands. No military school bands appeared. The planned marching contest was cancelled and half of the prize money set aside for this classification was distributed among the 10 bands ranked immediately below fourth place in the high school division.

On Thursday afternoon (June 6), all the high school bands that had remained at the pier or at the park after playing before the judge assembled at Grant Park for a parade and massed band concert. The parade was to proceed north on Michigan Avenue to the Drake Hotel, then countermarch back to the park. Apparently because a parade permit had not been secured, the concert was held first, followed by the announcement of winners. Then the 
bands marched on the sidewalk to the hotel. At least two of the bands dropped out of the parade to hurry to railroad depots for the last train of the day in their direction.

In reporting the results of the competition, Chicago papers listed the names of participating high school bands in the following order. The names of directors, when known to the writer, have been supplied in parentheses.

1. Fostoria, Ohio (John W. Wainwright), first prize, $\$ 1,000$.

2. Harrison Technical High School, Chicago (E. H. Kleffman), second prize, $\$ 500$.

3. Council Bluffs, Iowa (Lee M. Lockhart), third prize, $\$ 300$.

4. Hyde Park High School, Chicago (perhaps Charles J. King), fourth prize, $\$ 200$.

5. Richland Center, Wisconsin (Peter J. Michelsen), special award, $\$ 100$.

6. New Castle, Pennsylvania (La Verne E. Irvine), special award, $\$ 100$.

7. Paw Paw, Michigan (Arthur B. Castle), special award, $\$ 100$.

8. Allegheny High School, Pittsburgh, Pennsylvania (Ralph E. Blakeslee), special award, $\$ 100$.

9. Emerson High School, Gary, Indiana (Hubert S. Warren), special award, $\$ 100$.

10. Evansville, Indiana (Paul Baldwin), special award, $\$ 100$.

11. Cedar Rapids, Iowa (Frederick Doetzel), special award, $\$ 100$.

12. Male High School, Louisville, Kentucky (E. J. Wotawa), special award, $\$ 100$.

13. Rockford, Illinois ${ }^{8}$ (John $\mathrm{T}$.

\footnotetext{
${ }^{8}$ The Rockford band was the only one at the tournament to use high-pitch instruments. When
}

Haight), special award, $\$ 100$.

14. Elkhorn, Wisconsin (Henry W. Burch), special award, $\$ 100$.

15. Oklahoma City, Oklahoma (Floyd K. Russell).

16. Austin High School, Chicago (perhaps J. D. Henderson).

17. Lake Geneva, Wisconsin (L. H. McQueston).

18. Harvey, Illinois (Don C. Allen).

19. Lane Technical High School, Chicago.

20. Froebel High School, Gary, Indiana (Hubert S. Warren).

21. Calumet High School, Chicago (perhaps J. W. Fagan).

22. Bowen High School, Chicago.

23. Centerville, Iowa (Faye Lucille Rhodes).

24. Tilden High School, Chicago (A. W. Howard Stube).

25. Lindblom High School, Chicago.

26. Douglass High School, Hannibal, Missouri (Martin A. Lewis).

The four grammar school bands placed as follows:

1. Joliet, Illinois (Guido Mattei), first prize, $\$ 1,000$.

2. Harvey, Illinois (Don C. Allen), second prize, $\$ 500$.

3. Emerson School, Gary, Indiana (Melvin E. Snyder), third prize, $\$ 300$.

4. Glenwood School for Boys, Glenwood, Illinois (T. H. Davidson), fourth prize, $\$ 200$.

\section{Influence of the 1923 Contest}

In spite of its hurried planning and inept organization, the tournament was acclaimed by the music merchants as

the band was organized in 1907 , John T. Haight equipped the 20 piece band with instruments and music for $\$ 300$, buying used instruments at fantastically low prices. At that time American bands were just beginning to relinquish old Concert Pitch $(A=452.5)$ for the new International Concert Pitch $(A=440)$. 
a success. Even before the final concert and parade, Henry and industry leaders had discussed the continuation of the event under the sponsorship of the band instrument makers. However, a fortuitous conversation resulted in relinquishment of control of the tournament by the manufacturers and the involvement of the Committee on Instrumental Affairs of the Music Supervisors National Conference in the management of subsequent school music competitions.

At the massed band concert on Thursday, June 6, C. M. Tremaine appeared on the platform to present awards to the winning bands as secretary of the National Bureau for the Advancement of Music. During a lull in the program, he fell into conversation with Carl D. Greenleaf who described plans for the future of the tournament. Tremaine noted that such a project would lead to the commercialization of school bands. His experience with the promotion of music weeks, piano classes, and music appreciation courses had convinced him that no school music project could succeed unless control was vested in organizations of educators. Greenleaf then suggested that the National Bureau undertake the management of the 1924 contest. Tremaine agreed to do so if the industry would permit music educators to establish and enforce all regulations for entrance, repertoire, adjudication, and performance. It was agreed that Tremaine would seek the help of the Music Supervisors National Conference, that the National Bureau would provide the necessary executive services, and that the Band Instrument Manufacturers Association would provide funds without attempting to interfere with the operation of the contests.
Tremaine then approached members of the Committee on Instrumental Affairs of the Conference. As secretary of the Bureau, he had worked closely with each of the members and had apparently convinced them that the National Bureau could support and encourage school music projects without commercializing them. Somewhat reluctantly, the committee agreed to work out plans for a contest to be held in 1924.

The members of the committee (Jay W. Fay, chairman, Eugene M. Hahnel, B. F. Stuber, Victor L. F. Rebmann, and Russell V. Morgan) were unwilling to sponsor a "national" contest unless every section of the country could be represented. They therefore specified that a series of elimination contests, first in the several states and then in each of five regions, precede a national competition. No regional contest might be held until five state winners had been declared and no national contest could occur until at least three of the five regions had held competitions.

The committee was also reluctant to conduct a series of contests unless they could be made educational. Therefore, a repertoire list was developed from which a required number would be chosen each year and from which participating bands might select a second number. The repertoire list, patterned after an earlier list of orchestral materials compiled by Victor L. F. Rebmann and others, included symphonic movements, suites, overtures, and symphonic poems, representing a notable improvement over the then standard school band repertoire.

The provision for elimination contests and the creation of a repertoire list were in large measure responsible 
for the failure of the proposed 1924 national contest to materialize. Although contests were held in 13 states in 1924, only five were operated in accordance with the new rules. Ten states adopted the new regulations in 1925 and regional contests were held at Gary, Indiana, and Boston, Massachusetts. In 1926 15 states conducted official contests. Three regional contests ensued and the first official national contest was held at Fostoria, Ohio, with 13 bands representing 10 states.

At the Fostoria contest, the Joliet Township High School Band, directed by A. R. McAllister, became the new champion. Fostoria placed second; Ogden, Utah, was third; and Male High School of Louisville placed fourth. Other competing bands came from Ashtabula Harbor, Ohio; Council Bluffs, Iowa; Flint, Michigan; Grand Rapids, Michigan; Houston, Texas; Lockport, New York; Lowell, Massachusetts; Marion, Indiana; and Paw Paw, Michigan. The Fostoria contest was the occasion of the founding of the National School Band Association. The Association, later to replace the National $\mathrm{Bu}$ reau and the committee as the regulatory agency for band contests, was formed with the full support of the Bureau and the committee (now headed by Joseph E. Maddy). Membership in the Association was open to directors and students alike and permitted contestants to take advantage of reduced railroad fares for several years.

During the following years, the committee engaged in "The Battle of Band Instrumentation," as Maddy has called it. ${ }^{9}$ Reactionary efforts of directors, school officials, instrument manufacturers, and music publishers were com-

\footnotetext{
'Joseph E. Maddy, "The Battle of Band Instrumentation," Music Educators Journal, XLIV (September-October 1957), 30, 32, 35.
}

batted until the instrumentation of the modern symphonic school band had been perfected. The committee also prevailed upon publishers to provide full scores for competition selections. In 1929 the committee held national contests for school orchestras and instrumental soloists.

As state and national associations began to assume more and more responsibility, the National Bureau and the Conference gradually reduced their involvement. Yet the contest movement had achieved so much momentum that the great depression of the 1930's was unable to do more than to force the cancellation of the 1931 national contest. The number of contestants increased so rapidly that it became necessary to hold band and orchestra national contests in alternate years and later to declare that each regional competition was equivalent to a national contest.

The stimulation of competition immediately after the 1923 contest led to the establishment of schools for band directors, college curriculums for instrumental teachers, and the creation of the band clinic. State and national associations for instrumental teachers became forums for the discussion of problems and powerful devices for the improvement of standards. Simultaneously, the first national high school orchestra was assembled in Detroit by Joseph E. Maddy in 1926 and it electrified school administrators into the acceptance of instrumental music at the Dallas meeting of the Department of Superintendence of the National Education Association in 1927. Wainwright established the nation's first band camp near La Grange, Indiana, in 1926 and Maddy opened the National Music Camp at Interlochen the following year. The first decade of 
competition under the control of the Conference was concluded by the first national competitions for school choirs and instrumental ensembles.

Although every development of these fruitful years had roots in activities, ideas, and philosophies of long standing, the Schools Band Contest of America, conceived as an entertainment and promotional project, impelled leaders in music education and in the music industry to work together toward long- range goals by spectacular means. The results were amazing. Instrumental music was firmly established in the public schools of America. Enrollments increased phenomenally and performance standards reached heights unattainable by the casually organized bands and orchestras of the 1920's. For all its faults, the 1923 band tournament changed the course of music education history.

School of Music, University of Michigan 